\title{
Communication
}

\section{Nitrogen Removal by an Anaerobic Iron-Dependent Ammonium Oxidation (Feammox) Enrichment: Potential for Wastewater Treatment}

\author{
Carolina Rodríguez ${ }^{1}$, Jaime Cisternas ${ }^{1,2}$, Jennyfer Serrano ${ }^{2}$ and Eduardo Leiva ${ }^{1,3, *(D)}$ \\ 1 Departamento de Química Inorgánica, Facultad de Química y de Farmacia, Pontificia Universidad Católica \\ de Chile, Avenida Vicuña Mackenna 4860, Macul, Santiago 7820436, Chile; cnrodriguez@uc.cl (C.R.); \\ jaime.cisternas@mayor.cl (J.C.) \\ 2 Escuela de Biotecnología, Universidad Mayor, Camino La Pirámide 5750, Huechuraba, \\ Santiago 8580745, Chile; jennyfer.serrano@umayor.cl \\ 3 Departamento de Ingeniería Hidráulica y Ambiental, Pontificia Universidad Católica de Chile, \\ Avenida Vicuña Mackenna 4860, Macul, Santiago 7820436, Chile \\ * Correspondence: ealeiva@uc.cl; Tel.: +56-2-2354-7224; Fax: +56-2-2354-5876
}

check for updates

Citation: Rodríguez, C.; Cisternas, J.; Serrano, J.; Leiva, E. Nitrogen Removal by an Anaerobic Iron-Dependent Ammonium Oxidation (Feammox) Enrichment: Potential for Wastewater Treatment. Water 2021, 13, 3462. https:// doi.org/10.3390/w13233462

Academic Editors: Guoqiang Liu, Xin Zhou and Liang Zhang

Received: 2 November 2021

Accepted: 30 November 2021

Published: 6 December 2021

Publisher's Note: MDPI stays neutral with regard to jurisdictional claims in published maps and institutional affiliations.

Copyright: (c) 2021 by the authors. Licensee MDPI, Basel, Switzerland. This article is an open access article distributed under the terms and conditions of the Creative Commons Attribution (CC BY) license (https:// creativecommons.org/licenses/by/ $4.0 /)$.

\begin{abstract}
Nitrogen pollution in water is a growing concern. Anthropogenic activities have increased the amount of nitrogen released into watercourses, which harms human health and the environment, and causes serious problems, such as eutrophication. Feammox is a recently discovered biological pathway associated with the nitrogen cycle that has gained scientific interest. This process couples anaerobic ammonium oxidation with iron reduction. This work presents a study on the Feammox mechanism from the enrichment of an activated sludge obtained from a sewage treatment plant. The enrichment was carried out at neutral $\mathrm{pH}$ to study the $\mathrm{N}_{2}$ pathway, that is, the Feammox process with the oxidation of ammonium $\left(\mathrm{NH}_{4}{ }^{+}\right)$directly to $\mathrm{N}_{2}$. In addition, different sources of iron were studied: iron chloride $\left(\mathrm{FeCl}_{3}\right)$; ferrihydrite; and goethite. The characterization of the sludge showed the genes associated with ammonia monooxygenase, nitrate and nitrite reductases processes, along with relevant microbial species. The enrichment, carried out for 42 days and monitored every 14 days, showed that $\mathrm{FeCl}_{3}$ as a source of Fe was more effective for the coupled process of oxidation of $\mathrm{NH}_{4}{ }^{+}$ and the reduction of $\mathrm{Fe}(\mathrm{III})$ to $\mathrm{Fe}(\mathrm{II})$. At the end of the enrichment period, a removal of $31 \%$ and $32.2 \%$ of $\mathrm{NH}_{4}{ }^{+}$, and an increase in $\mathrm{Fe}(\mathrm{II})$ concentration by 52.4 and 63.9 times regarding the initial value were achieved in aerobic and anaerobic sludge, respectively. This study provides information on the potential of Feammox in the removal of $\mathrm{N}$ from wastewater, and the oxidation/reduction yields in the initial enrichment phase.
\end{abstract}

Keywords: Feammox; ammonium removal; iron reduction; microbial community; functional genes

\section{Introduction}

Nitrogen is one of the elements essential for life, building key cellular components, such as, nucleic acids, proteins, amino sugars, and amino lipids [1]. Nitrogen is found in nature mainly as dinitrogen $\left(\mathrm{N}_{2}\right)$, being the main constituent $(\sim 78 \%)$ of the earth's atmosphere [2]. However, $\mathrm{N}_{2}$ is fora chemical form that cannot be used by most organisms. Nitrogen fixation is a prokaryotic process with high energy expenditure, in which $\mathrm{N}_{2}$ is reduced to ammonium $\left(\mathrm{NH}_{4}{ }^{+}\right)$by $\mathrm{N}_{2}$-fixing bacteria and archaea [3]. Other prokaryotes and eukaryotes require fixed nitrogen (also known as reactive nitrogen) which corresponds to nitrogen forms as nitrate, ammonium, or organic nitrogen [2]. Microorganisms are also responsible for nitrification and denitrification processes. Nitrification is carried out by nitrifying bacteria which oxidize $\mathrm{NH}_{4}{ }^{+}$to nitrite $\left(\mathrm{NO}_{2}{ }^{-}\right)$and nitrate $\left(\mathrm{NO}_{3}{ }^{-}\right)$under aerobic conditions. Denitrification corresponds to an anaerobic process in which facultative heterotrophs reduce $\mathrm{NO}_{3}{ }^{-}$to nitrite and nitric oxide (NO) [4,5]. 
Although nitrogen compounds are essential nutrients for life, their substantial release into bodies of water, such as lakes and rivers, can cause eutrophication and severe damage to aquatic ecosystems [6-8]. Biological processes have commonly been the major focus for ammonium removal [8,9]. Among the most common biological processes, nitrification/denitrification and anammox stand out [9-13]. However, recently, adsorption technologies have been studied for the removal of ammonium from polluted waters [14]. Feammox is a recently discovered pathway for nitrogen loss in different ecosystems. Spe-cifically, Feammox mechanism couples anaerobic ammonium oxidation with iron reduc-tion, in the absence of nitrate or nitrite. Clément et al. [15] reported for the first time this ni-trogen loss pathway from a forested riparian wetland. Currently, treatment systems using Feammox has been primarily evaluated in laboratory-scale systems [11,16]. However, its use in large-scale treatment systems is promising, as it could be combined with other nitrogen removal techniques or replace other traditional methods that require aeration since Feammox has the advantage of being able to oxidize $\mathrm{NH}_{4}{ }^{+}$under anoxic conditions [17].

Iron $(\mathrm{Fe})$ is the fourth most abundant element on earth, occurring in different environments, typically in the redox states as Fe(II) (ferrous iron) and Fe(III) (ferric iron) [18]. This process, denominated Feammox (as anaerobic ammonium oxidation coupled to Fe(III) reduction) [19,20], generates the process of anaerobic oxidation of $\mathrm{NH}_{4}{ }^{+}$coupled to the reduction of iron ( $\mathrm{Fe}(\mathrm{III}))$ in the absence of oxygen, nitrate $\left(\mathrm{NO}_{3}{ }^{-}\right)$, or $\mathrm{NO}_{2}{ }^{-}$, which are required by annamox [21], as previously mentioned, and theoretically could occur abiotically or be microbially mediated [22]. In this reaction, $\mathrm{Fe}(\mathrm{III})$ is reduced to ferrous iron $\mathrm{Fe}(\mathrm{II})$, while $\mathrm{NH}_{4}{ }^{+}$is transformed to $\mathrm{NO}_{2}{ }^{-}$, nitrogen gas $\left(\mathrm{N}_{2}\right)$, or other forms of nitrogen as $\mathrm{NO}_{3}{ }^{-}$, with iron oxides [Ferric iron, $\mathrm{Fe}(\mathrm{III})$ ] as the electron acceptor [23]. Figure 1 illustrates the different general processes for the cycling of nitrogen species, as with Feammox, where $\mathrm{Fe}(\mathrm{III})$ is used and reduced together with the oxidation of $\mathrm{NH} 4+$ for the production of the different nitrogen species.

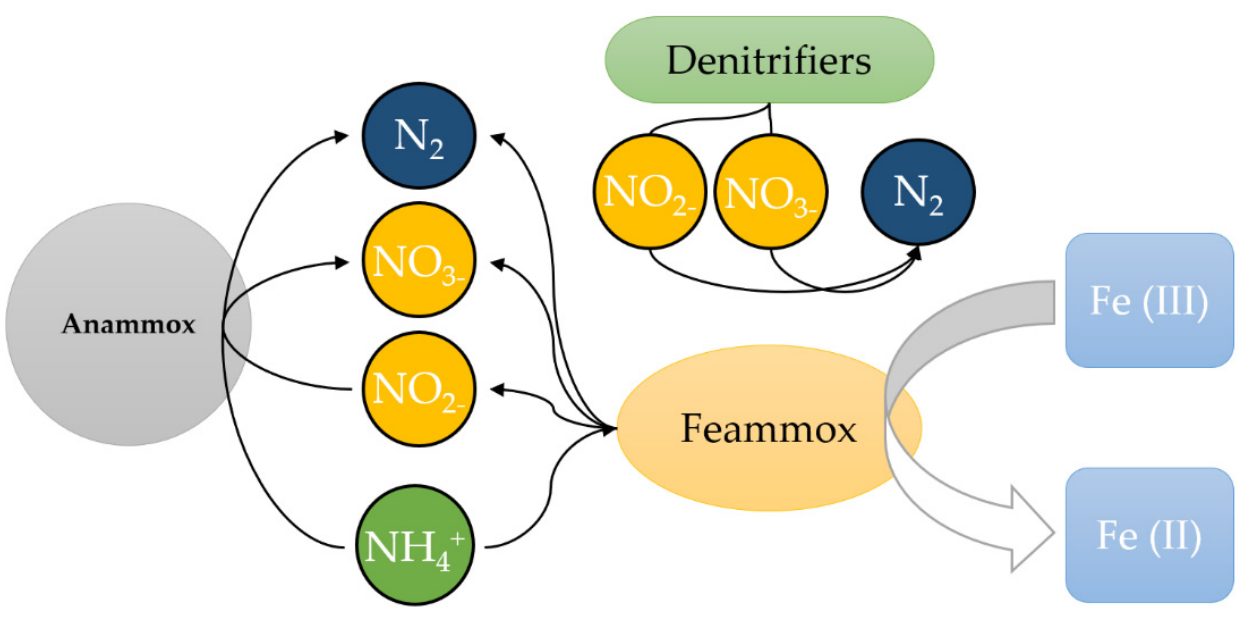

Figure 1. Illustrative diagram of the Anammox, denitrifiers, and Feammox process.

The Feammox process has been shown to produce either $\mathrm{N}_{2}, \mathrm{NO}_{2}{ }^{-}$, or $\mathrm{NO}_{3}{ }^{-}$as the end-product in several environments, as shown in Equations (1)-(3) [18]. Among these reactions, the $\mathrm{N}_{2}$ pathway is energetically more favorable than $\mathrm{NO}_{2}{ }^{-}$or $\mathrm{NO}_{3}{ }^{-}$pathways, and can occur over a wider range of conditions [22].

$$
\begin{gathered}
3 \mathrm{Fe}(\mathrm{OH})_{3}+5 \mathrm{H}^{+}+\mathrm{NH}_{4}{ }^{+} \rightarrow 3 \mathrm{Fe}^{2+}+9 \mathrm{H}_{2} \mathrm{O}+0.5 \mathrm{~N}_{2} \Delta \mathrm{rG}_{\mathrm{m}}=245 \mathrm{~kJ} \times \mathrm{mol}^{-1} \\
6 \mathrm{Fe}(\mathrm{OH})_{3}+10 \mathrm{H}^{+}+\mathrm{NH}_{4}^{+} \rightarrow 6 \mathrm{Fe}^{2+}+16 \mathrm{H}_{2} \mathrm{O}+\mathrm{NO}_{2}{ }^{-} \Delta \mathrm{rG}_{\mathrm{m}}=164 \mathrm{~kJ} \times \mathrm{mol}^{-1} \\
8 \mathrm{Fe}(\mathrm{OH})_{3}+14 \mathrm{H}^{+}+\mathrm{NH}_{4}{ }^{+} \rightarrow 8 \mathrm{Fe}^{2+}+21 \mathrm{H}_{2} \mathrm{O}+\mathrm{NO}_{3}{ }^{-} \Delta \mathrm{rG}_{\mathrm{m}}=207 \mathrm{~kJ} \times \mathrm{mol}^{-1}
\end{gathered}
$$


$\mathrm{NH}_{4}{ }^{+}$conversion to $\mathrm{NO}_{2}{ }^{-}$or $\mathrm{NO}_{3}{ }^{-}$is more likely to occur in acidic environments $(\mathrm{pH}<6.5)$ [11], and stoichiometrically requires more $\mathrm{Fe}(\mathrm{III})$. In addition, $\mathrm{NO}_{2}{ }^{-}$or $\mathrm{NO}_{3}{ }^{-}$ pathways produce less energy compared with the $\mathrm{N}_{2}$ reaction under the same conditions [22].

As for the microorganisms involved in the Feammox process, researchers have found that Acidimicrobiaceae sp. A6 [21] and other categories of iron-reducing bacteria (IRB), including Geobacter, Shewanella, Geothrix, Desulfosporosinus, Dechloromonas, unclassified Pelobacteraceae, and Anaeromyxobacter [24], are responsible for electron transfer in this reaction. In a recent study by Zhu et al. [24], they reported that Feammox activity is associated with the higher abundance of iron-reducing bacteria, especially Clostridium_sensu_stricto_12, Desulfitobacterium, Thermoanaerobaculum, Anaeromyxobacter, and Geobacter.

In this work, we study the Feammox process under different iron sources using an aerobic and an anaerobic sludge as inoculum obtained from two different treatment plants. The study focuses on the determination of ferric iron reduction coupled with the oxidation of $\mathrm{NH}_{4}{ }^{+}$. The $\mathrm{NH}_{4}{ }^{+}, \mathrm{Fe}(\mathrm{II})$, and $\mathrm{Fe}(\mathrm{III})$ were monitored in batch culture systems for 42 days. Also, we used PCR analysis to corroborate the presence of genes involved in this process. This study will allow for exploring the possible presence of Feammox activity in water treatment systems. In addition, the enrichment carried out at neutral $\mathrm{pH}$ could allow the identification of other microorganisms able of carrying out the Feammox process through the $\mathrm{N}_{2}$ pathway (Equation (1)), and, thus, increase knowledge about this process.

\section{Materials and Methods}

\subsection{Sludge Sample Collection}

The aerobic activated sludge sample was obtained from the "La Farfana" sewage treatment plant $\left(33^{\circ} 28^{\prime} 34.29^{\prime \prime} \mathrm{S}, 70^{\circ} 47^{\prime} 37.93^{\prime \prime} \mathrm{W}\right)$, and the anaerobic sludge was obtained from the yeast producer "Lefersa" ( $33^{\circ} 20^{\prime} 34.07^{\prime \prime}$ S, $70^{\circ} 42^{\prime} 53.99^{\prime \prime}$ W), both located in Santiago, Chile. The sample was collected in $1 \mathrm{~L} \mathrm{HDPE}$ bottles, and transported at $4{ }^{\circ} \mathrm{C}$ under dark until chemical and molecular analysis, and the pre-incubation process.

\subsection{Chemical Characterization of Sludge}

Chemical analyses were performed to characterize the sludge samples used in batch enrichment experiments. The total solids (TS) and volatile solids (VS) were determined according to Method $2540 \mathrm{G}$ from Standard Methods [25]. Also, the parameters of $\mathrm{pH}$, electrical conductivity (EC), and ammonium $\left(\mathrm{NH}_{4}{ }^{+}\right)$were measured directly from the sludge using HACH probes (PHC301, CDC401, ISENH4181, HACH, Loveland, CO, USA). Anions, iron species, chemical oxygen demand (COD), and soluble chemical oxygen demand (sCOD) were determined colorimetrically in a HACH spectrophotometer (DR3900, $\mathrm{HACH}, \mathrm{CO}, \mathrm{USA})$. The COD concentration was measured from a homogeneous sample of sludge. The anions, iron species, and sCOD were determined from filtered $(0.22 \mu \mathrm{m})$ supernatant fraction obtained from the sludge centrifugation at $6000 \mathrm{rpm}$ for $15 \mathrm{~min}$ (Hermle Z206A, Hermle Labortechnik GmbH, Wehingen, Germany). Figure 2 illustrates the procedure for obtaining samples used for the measurement of COD, SCOD, anions, and cations by spectrophotometry.

\subsection{DNA Isolation and PCR Analysis}

DNA samples were obtained from the aerobic and anaerobic sludges. DNA extraction from this sludge was carried out from $1000 \mu \mathrm{L}$ of sample using a DNeasy ${ }^{\circledR \circledR}$ PowerSoil $^{\circledR \circledR}$ Pro Kit (QIAGEN) as described by the manufacturer, except that pure nuclease-free water was used as a replacement for C6 solution. The quality of the DNA obtained was evaluated by agarose gel $(1.5 \%)$. After DNA extraction, the DNA samples were stored at $-20^{\circ}$ until polymerase chain reaction (PCR) analysis. 

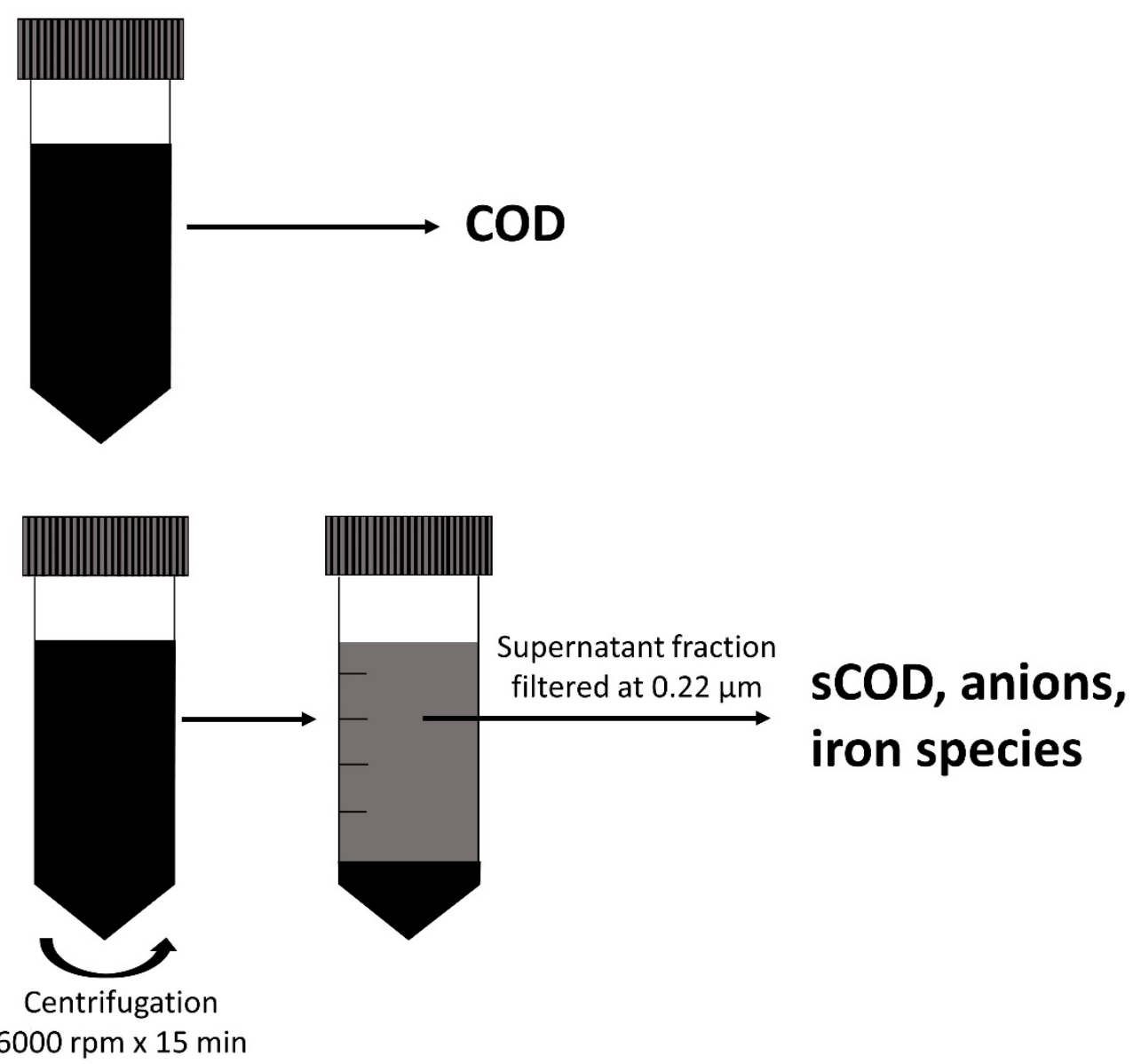

Figure 2. Procedure for obtaining samples for sludge characterization analysis.

PCR analysis was performed to evaluate the presence of genes involved in the Feammox process, such as functional genes and markers of relevant microbial species. The primer sets and the target genes evaluated are shown in Table A1, together with their melting temperature (MT) and the cycles used [26,27]. After each PCR program, the respective PCR products were evaluated by $1.5 \%$ agarose gel (run time $30 \mathrm{~min}$ at $90 \mathrm{~V}$. GeneRuler 1 $\mathrm{kb}$ (Cat. No: SM0311, Thermo Fisher Scientific Inc., MA, USA), and a 100 bp DNA ladder (Car. No: N3231S, New England BioLabs, MA, USA) was used to corroborate band size.

\subsection{Sludge Pre-Incubation}

The sludges were pre-incubated anaerobically at room temperature in the dark using $\mathrm{CO}_{2}$ as the purge gas, to remove any pre-existing electron acceptor, and to consume the organic carbon sources present. The pre-incubation was performed in a 100-mL culture flask for $24 \mathrm{~h}$ statically. Then, the culture was centrifuged at $6000 \mathrm{rpm}$ for $15 \mathrm{~min}$ (Hermle Z206A, Hermle Labortechnik GmbH, Wehingen, Germany), and the supernatant was used to measure the sCOD. For this, the supernatant was previously replaced with deionized water. The procedure was repeated four times, and the resulting sludge was used as the inoculum for batch experiments.

\subsection{Enrichment Culture in Batch Experiments}

For the enrichments, the pre-incubations were used as Feammox culture to be added. The base culture media contained $208 \mathrm{mg} / \mathrm{L} \mathrm{NH}_{4} \mathrm{Cl}, 600 \mathrm{mg} / \mathrm{L} \mathrm{KH}_{2} \mathrm{PO}_{4}, 112 \mathrm{mg} / \mathrm{L}$ $\mathrm{CaCl}_{2} \cdot 2 \mathrm{H}_{2} \mathrm{O}, 400 \mathrm{mg} / \mathrm{L} \mathrm{MgCl} 2 \cdot 6 \mathrm{H}_{2} \mathrm{O}, 2520.21 \mathrm{mg} / \mathrm{L} \mathrm{NaHCO}$. After autoclaving these media, $1 \mathrm{~mL}$ of vitamins $(1000 \times)$ and trace metals $(1000 \times)$ were added (filtered $(0.22 \mu \mathrm{m})$ ) under a laminar flow cabinet. The $\mathrm{pH}$ was adjusted to 7.0 depending on the iron source by adding $\mathrm{KOH}$ or $\mathrm{HCl}$ drop-wise. Then, the Fe source was added to these culture media 
considering four conditions: (i) without iron (-Fe); (ii) iron chloride $\left(\mathrm{FeCl}_{3}\right)$; (iii) ferrihydrite; and (iv) goethite. The cultures containing iron were adjusted to an iron concentration of $1 \mathrm{~g} / \mathrm{L}$. Ferrihydrite and goethite were ex-situ synthesized [28,29].

The media were transferred to $100 \mathrm{~mL}$ glass vials in duplicates for each condition. The cultures were incubated in the dark at room temperature using $\mathrm{CO}_{2}$ as the purge gas.

For each case, biotic and abiotic controls were evaluated. The enrichments were monitored every 14 days, for a total of 42 days. On each occasion, samples were collected, and ammonium, pH (ISENH4181, PHC301 HACH, Loveland, CO, USA), nitrate, total iron, and ferrous iron (spectrophotometer DR3900, $\mathrm{HACH}, \mathrm{CO}, \mathrm{USA}$ ) were measured.

\subsection{Quality Assurance/Quality Control (QA/QC)}

Quality assurance/quality control $(\mathrm{QA} / \mathrm{QC})$ procedures were performed for all the analyses in this study to ensure the quality, reproducibility, and accuracy of the obtained results. The equipment used in this study was calibrated before its use according to the instrument guidelines. All the chemical reagents used in this study were of analytical grade. Also, all materials used in the experiments were neatly cleaned and rinsed with Milli-Q water, and properly autoclaved. The accuracy and precision of the measurements were checked and compared against blank samples and synthetic standard samples of known concentration.

\section{Results and Discussion}

\subsection{Sludge Characterization}

To evaluate the potential of Feammox processes in wastewater treatment systems, a sample of activated sludge was used as inoculum for microbial enrichment. The activated sludge sample used in this study was characterized prior to conducting the enrichment experiments.

\subsubsection{Chemical Characterization}

Table 1 shows the chemical parameters in the activated sludge samples. $\mathrm{pH}$ had neutral values, with values of 6.93 and 7.85 for the aerobic and anaerobic sludge, respectively. The EC was $10.14 \mathrm{mS} / \mathrm{cm}$ in the aerobic sludge, and a slightly lower value of $7.85 \mathrm{mS} / \mathrm{cm}$ for the anaerobic sludge, which presented a higher value than that reported for other activated sludge [30,31], showing a higher concentration of ions. Ammonium concentration was very high in the aerobic sludge, with a value of $1420 \mathrm{mg} / \mathrm{L}$, which can be explained by the high $\mathrm{NH}_{4}{ }^{+}$concentrations of the influent sewage [32]. The ammonium concentration was much lower in the case of anaerobic sludge, with a value of $279 \mathrm{mg} / \mathrm{L}$. The total iron concentration in both sludges was quite low, which would not favor the activity of Feammox in the treatment system. Besides, the COD and sCOD concentrations presented high values because of the large amount of organic matter. These values made the preincubation stage necessary to reduce the initial COD conditions to evaluate the Feammox activity (autotrophic anaerobic ferric ammonium oxidation).

\subsubsection{Molecular Biology Characterization}

Molecular microbial analysis was used to explore the Feammox-related pathways in both activated sludges samples in order to determine the potential of the sample to enrich Feammox processes. PCR analyses are shown in Figure 3. The functional gene observed was archaea ammonia monooxygenase (amoA), whereas the relevant microbial species found were Geobacter spp., Shewanella spp., Ferrovum myxofaciens, Albidiferax ferrireducens, and Anammox bacteria. 
Table 1. Characterization of the aerobic and anaerobic sludge samples.

\begin{tabular}{|c|c|c|c|}
\hline & Parameter & Aerobic Sludge & Anaerobic Sludge \\
\hline & $\mathrm{pH}$ & 6.93 & 7.85 \\
\hline & $\mathrm{EC}[\mathrm{mS} / \mathrm{cm}]$ & 10.14 & 6.50 \\
\hline & $\mathrm{NH}_{4}^{+}[\mathrm{mg} / \mathrm{L}]$ & 1420.6 & 279 \\
\hline \multirow{4}{*}{ Anions } & $\mathrm{SO}_{4}^{2-}[\mathrm{mg} / \mathrm{L}]$ & 0 & 110 \\
\hline & $\mathrm{Cl}^{-}[\mathrm{mg} / \mathrm{L}]$ & 0.22 & 0.02 \\
\hline & $\mathrm{NO}_{3}{ }^{-}[\mathrm{mg} / \mathrm{L}]$ & 20.4 & 53.6 \\
\hline & $\mathrm{NO}_{2}^{-}[\mathrm{mg} / \mathrm{L}]$ & 0.1 & 0 \\
\hline \multirow{6}{*}{ Iron species } & Total Fe $[\mathrm{mg} / \mathrm{L}]$ & 0.52 & 0.35 \\
\hline & $\mathrm{Fe}^{2+}[\mathrm{mg} / \mathrm{L}]$ & 0 & 0.1 \\
\hline & $\mathrm{COD}[\mathrm{mg} / \mathrm{L}]$ & 76,100 & 51,303 \\
\hline & $\mathrm{sCOD}[\mathrm{mg} / \mathrm{L}]$ & 14,019 & 3567 \\
\hline & TS & $2.74 \%$ & $5.23 \%$ \\
\hline & VS & $2.11 \%$ & $4.45 \%$ \\
\hline
\end{tabular}

A.

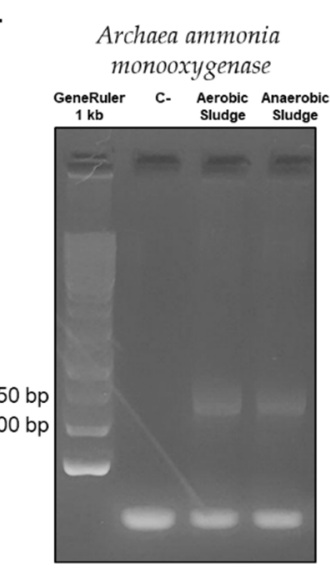

D.

Ferrovum myxofaciens

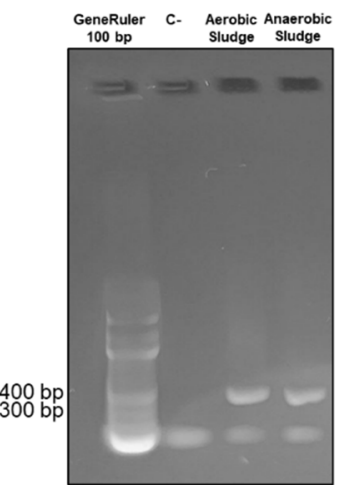

B.

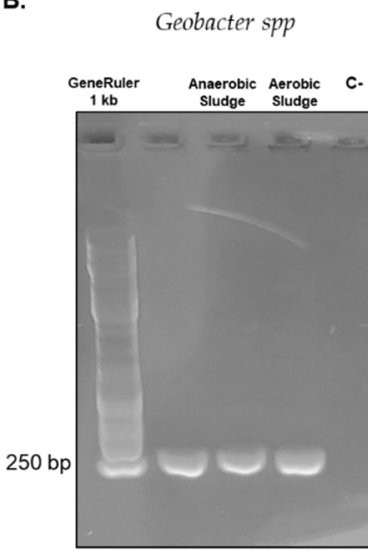

E.

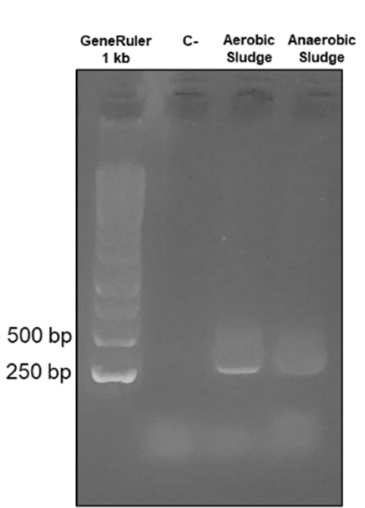

C.

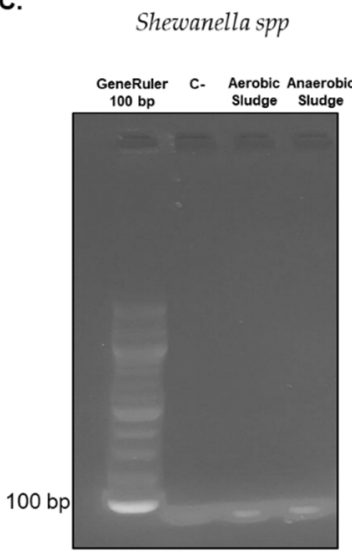

F.

Anammox bacteria

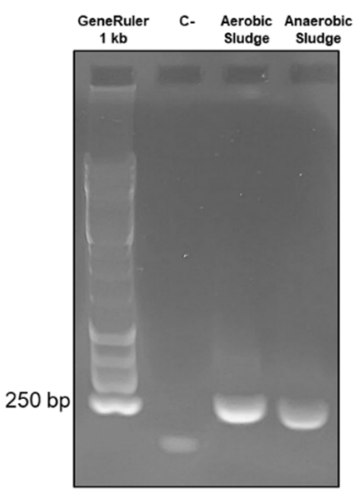

Figure 3. Electrophoresis gels PCR products to check for the presence of relevant Feammox genes. (A). amoAF AOA-amoAR AOA primers (Ammonia-oxidizing archaea, 635 bp), (B). Geo546FGeo840R primers (Geobacter spp., 276 bp), (C). She120F- She220R primers (Shewanella spp., 100 bp), (D). Ferrovum643F-Uni-338F-RC primers (Ferrovum myxofaciens, 323 bp), (E). Uni-907R-RdoR-RC primers (Albidiferax ferrireducens, 312 bp), (F). AMX809F-AMX1066R, respectively (anammox bacteria, $239 \mathrm{bp}$ ). The PCR conditions are shown in Table A1 (Appendix A). The list of all primer sets tested is shown in Table A1 (Appendix A).

The aforementioned genes and their targets are related to Feammox processes. The results showed the presence of archaea ammonia monooxygenase gene, a key enzyme for 
nitrification and for the global nitrogen cycle [33,34]. The beginning of the nitrification process occurs through the oxidation of ammonia $\left(\mathrm{NH}_{3}\right)$ to hydroxylamine $\left(\mathrm{NH}_{2} \mathrm{OH}\right)$, a reaction catalyzed by the enzyme ammonia monooxygenase [33]. Ammonia-oxidizing archaea are closely associated with denitrifiers, and play a critical role in coupled nitrificationdenitrification [35]. Bacterial AmoA was not amplified, which is explained because archaeal AmoA is more widespread than bacterial AmoA in sedimentary environments [35].

Regarding Geobacter and Shewanella, their presence may be associated with a Feammox process because these two were among the first bacteria studied in a pure culture that can obtain energy for growth by coupling the oxidation of organic matter with iron reduction, and are considered the model iron reducers [36,37]. Similarly, Albidiferax ferrireducens, previously recognized as Rhodoferax ferrireducens [38], is classified as a FeRM (iron-reducing microorganism). Therefore, it grows in Fe(III)-rich environments, and reduces it to ferrous iron $[39,40]$. At the same time, Ferrovum myxofaciens uses only ferrous iron as electron donor, and oxygen as electron acceptor. It is found exclusively in iron-rich acidic waters [41].

Finally, the anammox bacteria are typical of wastewater sludge [42], and are bacteria that anaerobically oxidize ammonium with nitrite to $\mathrm{N}_{2}$ [43], which explains its presence in the sample. This is consistent with the presence of simultaneous Feammox processes.

From these results, the diversity of microorganisms and reactions related to Feammox can be seen. The presence of these genes in the initial sludges samples suggests a high potential to find Feammox activity from the enrichments, and to select those microorganisms that exhibit potential for $\mathrm{NH}_{4}{ }^{+}$oxidation and Fe(III) reduction under conditions of high Fe concentration.

\subsection{Sludge Pre-Incubation}

The sCOD values were monitored daily during the pre-incubation process. In the aerobic sludge, during the first two days, sCOD decreased by $73 \%$, and then stabilized between days 3 and 4 of pre-incubation. After this period, a $90 \%$ reduction in the initial sCOD was achieved. For the anaerobic sludge, sCOD continuously decreased to a $90 \%$ reduction on the fourth day. These results are shown in Figure 4.

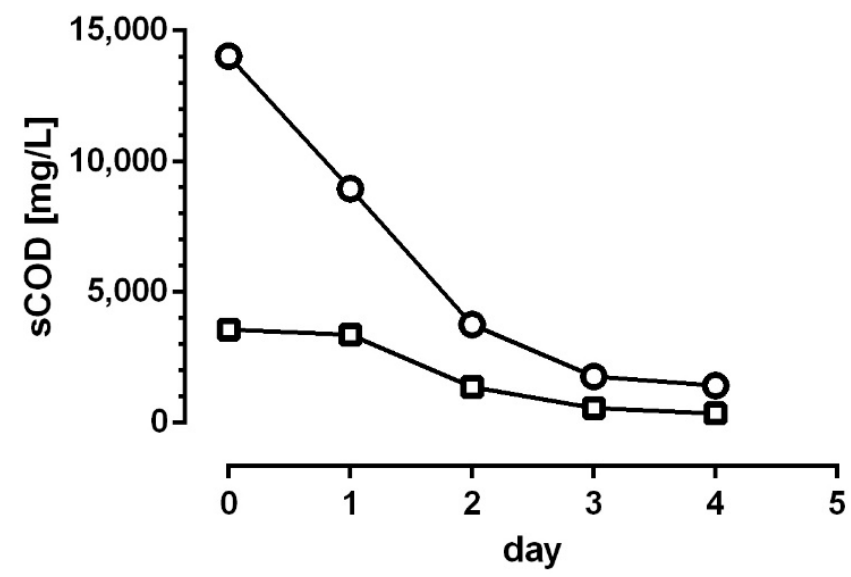

Figure 4. The concentration of SCOD during the preincubation process.

\subsection{Enrichment Culture in Batch Experiments}

Feammox enrichment was carried out using aerobic and anaerobic sludge samples. A microbial enrichment was able to enhance a Feammox culture capable of oxidizing $\mathrm{NH}_{4}{ }^{+}$ and reducing $\mathrm{Fe}(\mathrm{III})$ in 42 days. A decrease in $\mathrm{NH}_{4}{ }^{+}$levels and an increase in $\mathrm{Fe}(\mathrm{II})$ were observed. Figure 5A-F shows that in the three cases with different iron sources in the aerobic sludge, a decrease in $\mathrm{NH}_{4}{ }^{+}$levels was observed, together with an increase in $\mathrm{Fe}$ (II) and nitrate $\left(\mathrm{NO}_{3}{ }^{-}\right)$levels. When $\mathrm{FeCl}_{3}$ was used (Figure $\left.5 \mathrm{~A}, \mathrm{~B}\right)$, the initial $\mathrm{NH}_{4}{ }^{+}$concentration was decreased by $31 \%$ over the enrichment period. As for the Fe(II) concentration, it was possible to increase it by 52.4 times the initial concentration (from 0.0069 to $0.3616 \mathrm{mmol}$ ), and $\mathrm{NO}_{3}{ }^{-}$by 3.3 times. With ferrihydrite (Figure $5 \mathrm{C}, \mathrm{D}$ ), the total $\mathrm{NH}_{4}{ }^{+}$was consumed by 
$20.5 \%$, the initial value of $\mathrm{Fe}(\mathrm{II})$ was increased by 41.6 times (from 00025 to $0.1041 \mathrm{mmol}$ ), and the value of $\mathrm{NO}_{3}{ }^{-}$by 2 times. With goethite (Figure $5 \mathrm{E}, \mathrm{F}$ ), it was possible to decrease by $37.5 \%$ of the total initial $\mathrm{NH}_{4}{ }^{+}$. $\mathrm{Fe}$ (II) was increased by 11.4 times its initial value (from 0.0025 to $0.0285 \mathrm{mmol}$ ), and $\mathrm{NO}^{-}$by 1.5 times. The Fe(III) concentration was relatively stable, which can be explained by its higher initial concentration. In the enrichment's case, carried out using an anaerobic activated sludge, a similar behavior to the aerobic sludge could be observed in terms of the parameters measured. When $\mathrm{FeCl}_{3}$ was used (Figure 5A,B), the initial ammonium concentration was decreased by $32.23 \%$. As for $\mathrm{Fe}(\mathrm{II})$, the initial concentration increased by 63.9 times (from 0.0069 to $0.4414 \mathrm{mmol}$ ), and NO3 ${ }^{-}$ by 2.2 times. With ferrihydrite (Figure $5 \mathrm{C}, \mathrm{D}$ ), the initial $\mathrm{NH}_{4}{ }^{+}$concentration was consumed by $21.25 \%$, and the $\mathrm{Fe}$ (II) concentration was increased by 57.62 times compared to the initial concentration (from 0.0025 to $0.1440 \mathrm{mmol}$ ). The $\mathrm{NO}^{-}$was increased by 2.34 times. When goethite was used (Figure $5 \mathrm{E}, \mathrm{F}$ ), the initial $\mathrm{NH}_{4}{ }^{+}$concentration was reduced by $36.12 \%$. The initial concentration of $\mathrm{Fe}(\mathrm{II})$ was increased by 31.7 times (from 0.0025 to $0.0792 \mathrm{mmol}$ ), and for $\mathrm{NO}^{-}$by 1.3 times. In Figure $5 \mathrm{G}$, it can be seen that without $\mathrm{Fe}$, the $\mathrm{NH}_{4}{ }^{+}$and $\mathrm{NO}^{-}$ remain stable over time, which supports that the variation in the concentrations of these nitrogen species is associated with the presence of iron-dependent microorganisms. For each culture condition, abiotic controls were monitored in which the initial concentration of $\mathrm{NO}_{3}{ }^{-}$and $\mathrm{Fe}(\mathrm{II})$ was kept constant over time, whereas the sludge increases these levels. This is related to the expected Feammox behavior.

The results obtained for the aerobic and anaerobic sludge were analyzed by analysis of variance (ANOVA) to determine if the differences obtained in the measurements for each type of sludge have statistical significance. For this analysis, a significance level of $\alpha=0.05$ was applied, using $p$-value $<0.05$ for comparing cases. This analysis showed that for cultures with $\mathrm{FeCl}_{3}$ and ferrihydrite as iron sources, the differences between each inoculum did not have statistical significance for the measurements of $\mathrm{NH}_{4}{ }^{+}, \mathrm{NO}_{3}{ }^{-}$, and $\mathrm{Fe}(\mathrm{II})$, so it cannot be deduced that one of the sludges is better than the other in its performance. For the case of goethite, the ammonium measurements did not have a significant difference. However, the measurements of $\mathrm{NO}_{3}{ }^{-}$and $\mathrm{Fe}(\mathrm{II})$ had differences with statistical significance, with a $p$-value of 0.028 and 0.019 , respectively, so it can be concluded that the anaerobic sludge was significantly better in the production of $\mathrm{NO}_{3}{ }^{-}$, and the reduction of $\mathrm{Fe}$ (III) to Fe(II) than aerobic sludge. This can be explained because of the microbial community present in the anaerobic sludge, which is naturally acclimated to anoxic conditions as used in the experimental setup. Therefore, it would not require an anaerobic adaptation step.

As previously mentioned, Feammox produces the anaerobic oxidation of $\mathrm{NH}_{4}{ }^{+}$to $\mathrm{NO}_{3}{ }^{-}, \mathrm{NO}_{2}{ }^{-}$or $\mathrm{N}_{2}$, together with the reduction of $\mathrm{Fe}(\mathrm{III})$ to $\mathrm{Fe}(\mathrm{II})$ [44]. This behavior is consistent with our results, where the decay of $\mathrm{NH}_{4}{ }^{+}$together with the rise of $\mathrm{Fe}(\mathrm{II})$ were observed. Other studies have shown similar trends [11,21,45-48]. Similar behavior was found for the concentrations of $\mathrm{NH}_{4}{ }^{+}, \mathrm{NO}_{3}{ }^{-}$, and $\mathrm{Fe}(\mathrm{II}$ and III), with different values for the removal rates and days of residence. As for the iron source, Huang et al. [21] and Huang et al. [46] studied the effect of the iron source on Feammox enrichment from isolates, and proposed that the best iron source in terms of $\mathrm{NH}_{4}{ }^{+}$removal and $\mathrm{Fe}(\mathrm{III})$ reduction was ferrihydrite, followed by goethite, and finally, $\mathrm{FeCl}_{3}$. This can be explained due to the higher thermodynamic feasibility of ferrihydrite compared to goethite as a source of $\mathrm{Fe}(\mathrm{III})$, since ferrihydrite has a higher negative Gibbs free energy than goethite [18]. However, our results showed that when using goethite, the highest $\mathrm{NH}_{4}{ }^{+}$removal was obtained, followed by $\mathrm{FeCl}_{3}$ and ferrihydrite in both cases, anaerobic and aerobic. The highest $\mathrm{Fe}$ (III) to $\mathrm{Fe}$ (II) reduction occurs when using $\mathrm{FeCl}_{3}$, followed by ferrihydrite and goethite, respectively, in both sludges. This can be explained due to the ability of the activated sludge to adapt to use different iron sources. As for nitrate $\left(\mathrm{NO}_{3}{ }^{-}\right)$, an increase can be observed in all the different conditions, as in the process described in equation 3 , although the direct production to $\mathrm{N}_{2}$ is the most favorable and, therefore, the most expected. However, the different production rates in the studies are not always consistent with the theory, as Feammox to $\mathrm{NO}_{3}{ }^{-}$was also thermodynamically feasible under these conditions $[18,22]$. Furthermore, ammonium 
reduction under Fe-rich anaerobic conditions is consistent with what has been previously reported for Feammox processes in natural systems.

A.
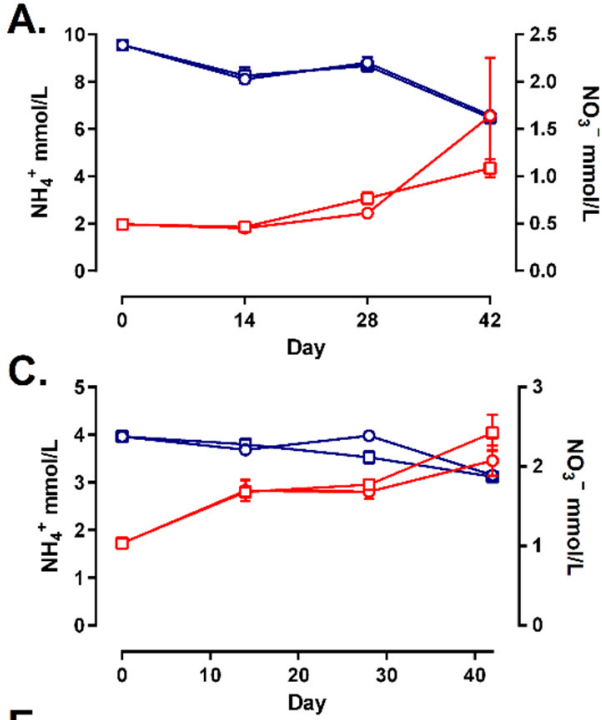

E.
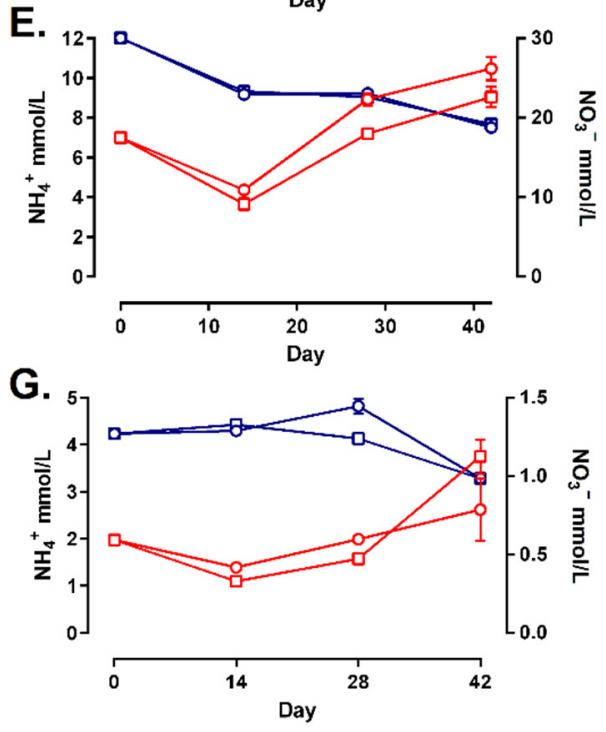

B.
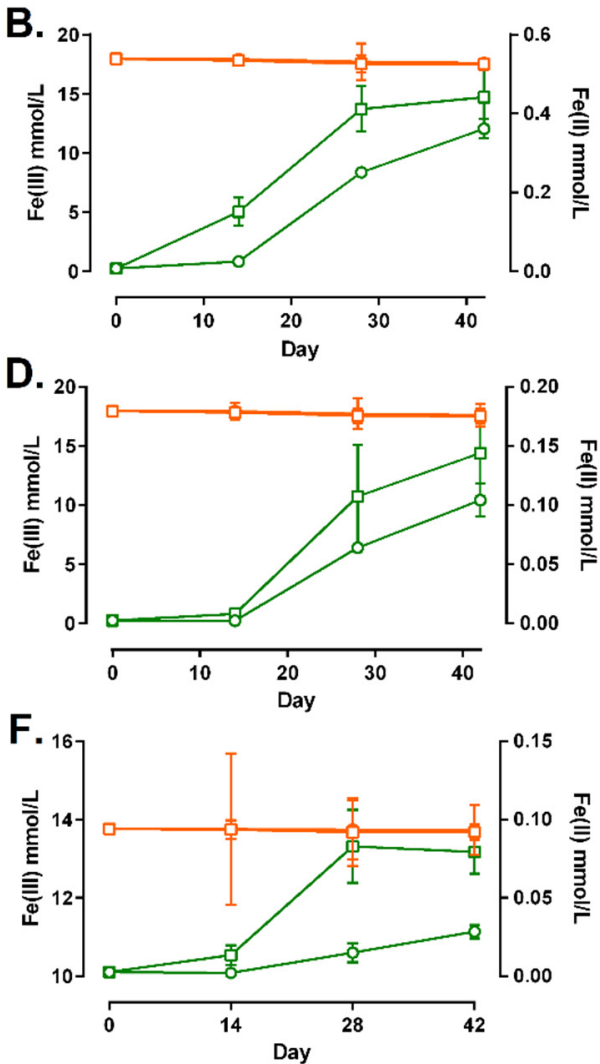

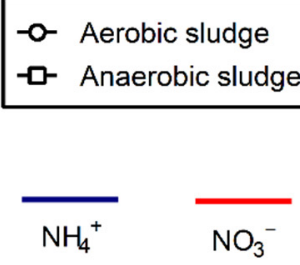

$\mathrm{Fe}(\mathrm{III}) \quad \mathrm{Fe}(\mathrm{II})$

Figure 5. Concentration of $\mathrm{NH}_{4}{ }^{+}, \mathrm{NO}_{3}{ }^{-}, \mathrm{Fe}(\mathrm{II})$, and $\mathrm{Fe}(\mathrm{III})$ over 42 days of incubation, and measurements using different iron sources: (A,B) $\mathrm{FeCl}_{3}$; (C,D) ferrihydrite; (E,F) gothite; and (G) without Fe (control). The concentrations of the different parameters were grouped on the right and left y-axes, in order to be easily visualized.

\section{Conclusions}

The study of the presence of Feammox activity from the enrichment of an activated sludge showed successful results in terms of ammonium removal by the Feammox process. The enrichment was able to enhance a Feammox culture capable of oxidizing $\mathrm{NH}_{4}{ }^{+}$and reducing Fe(III) in 42 days. PCR analysis revealed the presence of certain relevant genes associated with Feammox activity, such as archaea ammonia monooxygenase (amoA), and relevant microbial species, such as Geobacter spp., Shewanella spp., Ferrovum myxofaciens, Albidiferax ferrireducens, and Anammox bacteria. The enrichment using different iron types showed that the best iron source in terms of $\mathrm{NH}_{4}{ }^{+}$removal, along with the reduction of $\mathrm{Fe}(\mathrm{III})$ to $\mathrm{Fe}(\mathrm{II})$, was $\mathrm{FeCl}_{3}$. Although goethite presents a higher percentage of $\mathrm{NH}_{4}{ }^{+}$ removal, it is the source with the lowest Fe(III) reduction rate, so a very direct relationship to Feammox could not necessarily be established.

Our preliminary findings confirm the presence of the Feammox process in a wastewater sludge sample, which can contribute to understanding how these processes can be 
enhanced in order to improve nitrogen removal processes in wastewater. Thus, this article contributes to the gaining of knowledge of the Feammox process by providing more information for a better understanding of the process, along with the use of activated sludge from aerobic and anaerobic sources. It also tests the different iron sources and their reduction capacity, along with the oxidation of $\mathrm{NH}_{4}{ }^{+}$. These results can be critical for scaling these processes to more realistic systems by understanding where Feammox processes are most efficient or in which environments they are most prevalent. Even so, additional efforts are necessary to fully understand this process and the conditions that promote its prevalence.

Author Contributions: The manuscript was written by J.C. and C.R., but all the authors contributed to its preparation and review. Experiments were performed by J.C. and C.R.; Data analyses were carried out by J.C. and C.R. in discussion with J.S. and E.L. All authors have read and agreed to the published version of the manuscript.

Funding: This research was funded by FONDECYT Iniciación 11191154 (2019-2022).

Institutional Review Board Statement: Not applicable.

Informed Consent Statement: Not applicable.

Data Availability Statement: The data presented in this study are available on request from the corresponding author.

Acknowledgments: Thanks are also extended to the reviewers for their corrections and suggestions, who contributed significantly to improving the quality of this manuscript.

Conflicts of Interest: The authors declare no conflict of interest.

\section{Appendix A}

Table A1. Primer sets, characteristics, and PCR cycles.

\begin{tabular}{|c|c|c|c|c|c|}
\hline Primers & $\begin{array}{l}\text { Tm } \\
\left({ }^{\circ} \mathrm{C}\right)\end{array}$ & Sequence & $\begin{array}{c}\text { Band } \\
\text { Lenght }\end{array}$ & PCR Cycles & Target \\
\hline ACD840 & 53.5 & $\begin{array}{c}\text { CGA CAC TGA AGT } \\
\text { GCT AAG C }\end{array}$ & 505 bp & $\begin{array}{l}\text { Pre-heating at } 50^{\circ} \mathrm{C} \text { for } 2 \mathrm{~min} \text {, } \\
\text { pre-denaturation at } 95^{\circ} \mathrm{C} \text { for } \\
10 \text { min, denaturation at } 95^{\circ} \mathrm{C} \text { for } \\
15 \mathrm{~s} \text {, annealing at } 61^{\circ} \mathrm{C} \text { for } 45 \mathrm{~s} \text {, and } \\
\text { extension at } 72^{\circ} \mathrm{C} \text { for } 45 \mathrm{~s}\end{array}$ & $\begin{array}{l}\text { FeRB (Acidiphilium } \\
\text { spp.) }\end{array}$ \\
\hline Uni-338F-RC & 59.4 & $\begin{array}{c}\text { ACT CCT ACG GGA } \\
\text { GGC AGC }\end{array}$ & & & \\
\hline amoAF AOA & 52.6 & $\begin{array}{l}\text { STA ATG GTC TGG } \\
\text { CTT AGA CG }\end{array}$ & $635 \mathrm{bp}$ & $\begin{array}{c}3 \text { min at } 94{ }^{\circ} \mathrm{C} \text {, followed by } \\
40 \text { cycles of } 30 \mathrm{~s} \text { at } 94{ }^{\circ} \mathrm{C}, 1 \mathrm{~min} \text { at } \\
53^{\circ} \mathrm{C} \text {, and } 1 \mathrm{~min} \text { at } 72^{\circ} \mathrm{C}\end{array}$ & $\begin{array}{c}\text { Archaea ammonia } \\
\text { monoooxygenase } \\
\text { (AOA-amoA) }\end{array}$ \\
\hline amoAR AOA & 57.5 & $\begin{array}{c}\text { GCG GCC ATC CAT } \\
\text { CTG TAT GT }\end{array}$ & & & \\
\hline $\begin{array}{l}\text { amoAF AOB } \\
\text { amoAR AOB }\end{array}$ & $\begin{array}{l}54.1 \\
59.2\end{array}$ & $\begin{array}{l}\text { GGG GTT TCT ACT } \\
\text { GGT GGT } \\
\text { CCC CTC KGS AAA } \\
\text { GCC TTC TTC }\end{array}$ & $471 \mathrm{bp}$ & $\begin{array}{c}3 \text { min at } 94{ }^{\circ} \mathrm{C} \text {, followed by } \\
40 \text { cycles of } 30 \mathrm{~s} \text { at } 94^{\circ} \mathrm{C}, 30 \mathrm{~s} \text { at } \\
55^{\circ} \mathrm{C} \text {, and } 45 \mathrm{~s} \text { at } 72{ }^{\circ} \mathrm{C}\end{array}$ & $\begin{array}{l}\text { Bacteria ammonia } \\
\text { monoooxygenase } \\
\text { (AOB-amoA) }\end{array}$ \\
\hline AMX809F & $\begin{array}{l}59.5 \\
58.2\end{array}$ & $\begin{array}{l}\text { AAC GTC TCA CGA } \\
\text { CAC GAG CTG } \\
\text { GCC GTA AAC GAT } \\
\text { GGG CAC T }\end{array}$ & $239 \mathrm{bp}$ & $\begin{array}{c}10 \mathrm{~min} \text { at } 95^{\circ} \mathrm{C} \text {, followed by } \\
35 \text { cycles of } 60 \mathrm{~s} \text { at } 95^{\circ} \mathrm{C}, 60 \mathrm{~s} \text { at } \\
60^{\circ} \mathrm{C} \text {, and } 45 \mathrm{~s} \text { at } 72^{\circ} \mathrm{C}\end{array}$ & Anammox Bacteria \\
\hline AMX818F & 60 & $\begin{array}{c}\text { ATG GGC ACT MRG } \\
\text { TAG AGG GGT TT }\end{array}$ & $228 \mathrm{bp}$ & & \\
\hline
\end{tabular}


Table A1. Cont.

\begin{tabular}{|c|c|c|c|c|c|}
\hline Primers & $\begin{array}{l}\mathrm{Tm} \\
\left({ }^{\circ} \mathrm{C}\right)\end{array}$ & Sequence & $\begin{array}{l}\text { Band } \\
\text { Lenght }\end{array}$ & PCR Cycles & Target \\
\hline Geo564F & 49.8 & $\begin{array}{l}\text { AAG CGT TGT TCG } \\
\text { GAW TTA T }\end{array}$ & & $\begin{array}{l}\text { Pre-heating at } 50^{\circ} \mathrm{C} \text { for } 2 \mathrm{~min}, \\
\text { pre-denaturation at } 95^{\circ} \mathrm{C} \text { for }\end{array}$ & \\
\hline Geo840R & 57.6 & $\begin{array}{l}\text { GGC ACT GCA GG } \\
\text { GGT CAA TA }\end{array}$ & $276 \mathrm{bp}$ & $\begin{array}{c}10 \mathrm{~min} \text {, denaturation at } 94^{\circ} \mathrm{C} \text { for } \\
30 \mathrm{~s} \text {, annealing at } 57^{\circ} \mathrm{C} \text { for } 30 \mathrm{~s} \text {, and } \\
\text { extension at } 72^{\circ} \mathrm{C} \text { for } 30 \mathrm{~s} \\
(40 \text { cycles })\end{array}$ & $\begin{array}{l}\text { FeRB (Geobacter } \\
\text { spp.) }\end{array}$ \\
\hline napA3F & 56.9 & $\begin{array}{c}\text { CCC AAT GCT CGC } \\
\text { CAC TG }\end{array}$ & \multirow[b]{2}{*}{$130 \mathrm{bp}$} & \multirow{2}{*}{$\begin{array}{c}5 \text { min at } 95^{\circ} \mathrm{C} \text {, followed by } \\
35 \text { cycles of } 60 \mathrm{~s} \text { at } 95^{\circ} \mathrm{C}, 60 \mathrm{~s} \text { at } \\
60{ }^{\circ} \mathrm{C} \text {, and } 45 \mathrm{~s} \text { at } 72{ }^{\circ} \mathrm{C}\end{array}$} & $\begin{array}{c}\text { Functional genes } \\
\text { (napA) }\end{array}$ \\
\hline napA3R & 55.1 & $\begin{array}{c}\text { CAT GTT KGA GCC } \\
\text { CCA CAG }\end{array}$ & & & $\begin{array}{l}\text { Dissimilarity } \\
\text { nitrite reducing } \\
\text { bacteria }\end{array}$ \\
\hline narG2F & 53.8 & $\begin{array}{l}\text { CTC GAY CTG GTG } \\
\text { GTY GA }\end{array}$ & \multirow[b]{2}{*}{$89 \mathrm{bp}$} & \multirow{2}{*}{$\begin{array}{c}5 \text { min at } 95^{\circ} \mathrm{C} \text {, followed by } \\
35 \text { cycles of } 60 \mathrm{~s} \text { at } 95^{\circ} \mathrm{C}, 60 \mathrm{~s} \text { at } \\
55^{\circ} \mathrm{C} \text {, and } 45 \mathrm{~s} \text { at } 72{ }^{\circ} \mathrm{C}\end{array}$} & $\begin{array}{c}\text { Functional genes } \\
\text { (narG) }\end{array}$ \\
\hline narG2R & 53.2 & $\begin{array}{l}\text { TTY TCG TAC CAG } \\
\text { GTS GC }\end{array}$ & & & $\begin{array}{l}\text { Dissimilarity } \\
\text { nitrite reducing } \\
\text { bacteria }\end{array}$ \\
\hline nirKF & 59.9 & $\begin{array}{l}\text { ATY GGC GGV AYG } \\
\text { GCG A }\end{array}$ & \multirow[b]{2}{*}{$165 \mathrm{bp}$} & \multirow{2}{*}{$\begin{array}{c}5 \mathrm{~min} \text { at } 95^{\circ} \mathrm{C} \text {, followed by } \\
35 \text { cycles of } 60 \mathrm{~s} \text { at } 95^{\circ} \mathrm{C}, 60 \mathrm{~s} \text { at } \\
57^{\circ} \mathrm{C} \text {, and } 45 \mathrm{~s} \text { at } 72{ }^{\circ} \mathrm{C}\end{array}$} & \multirow{2}{*}{$\begin{array}{c}\text { Functional genes } \\
\text { (nirK) } \\
\text { Denitrifying } \\
\text { bacteria }\end{array}$} \\
\hline nirKR & 52.8 & $\begin{array}{l}\text { GCC TCG ATC AGR } \\
\text { TTR TGG }\end{array}$ & & & \\
\hline nirSnF & 69.1 & $\begin{array}{l}\text { TAC CAC CCC GAG } \\
\text { CCG CGC GT }\end{array}$ & \multirow[b]{2}{*}{164 bp } & \multirow{2}{*}{$\begin{array}{c}5 \mathrm{~min} \text { at } 95^{\circ} \mathrm{C} \text {, followed by } \\
35 \text { cycles of } 60 \mathrm{~s} \text { at } 95^{\circ} \mathrm{C}, 60 \mathrm{~s} \text { at } \\
63^{\circ} \mathrm{C} \text {, and } 45 \mathrm{~s} \text { at } 72{ }^{\circ} \mathrm{C}\end{array}$} & \multirow{2}{*}{$\begin{array}{c}\text { Gnes funcionales } \\
\text { (nirS) } \\
\text { Denitrifying } \\
\text { bacteria }\end{array}$} \\
\hline nirSnr & 61.6 & $\begin{array}{l}\text { GCC GCC GTC RTG } \\
\text { VAG GAA }\end{array}$ & & & \\
\hline $\operatorname{nos} Z 1 F$ & 59.5 & $\begin{array}{l}\text { WCS YTG TTC MTC } \\
\text { GAC AGC CAG }\end{array}$ & \multirow[b]{2}{*}{$259 \mathrm{bp}$} & \multirow{2}{*}{$\begin{array}{c}5 \text { min at } 95^{\circ} \mathrm{C} \text {, followed by } \\
35 \text { cycles of } 60 \mathrm{~s} \text { at } 95^{\circ} \mathrm{C}, 60 \mathrm{~s} \text { at } \\
63^{\circ} \mathrm{C} \text {, and } 45 \mathrm{~s} \text { at } 72^{\circ} \mathrm{C}\end{array}$} & \multirow{2}{*}{$\begin{array}{c}\text { Functional genes } \\
\text { (nosZ) } \\
\text { Denitrifying } \\
\text { bacteria }\end{array}$} \\
\hline nosZ1R & 56.8 & $\begin{array}{l}\text { ATG TCG ATC ARC } \\
\text { TGV KCR TTY TC }\end{array}$ & & & \\
\hline nrfA2F & 59.1 & $\begin{array}{c}\text { CAC GAC AGC AAG } \\
\text { ACT GCC G }\end{array}$ & \multirow[b]{2}{*}{$67 \mathrm{bp}$} & \multirow{2}{*}{$\begin{array}{c}5 \text { min at } 95^{\circ} \mathrm{C} \text {, followed by } \\
35 \text { cycles of } 60 \mathrm{~s} \text { at } 95^{\circ} \mathrm{C}, 60 \mathrm{~s} \text { at } \\
60^{\circ} \mathrm{C} \text {, and } 45 \text { s at } 72^{\circ} \mathrm{C}\end{array}$} & \multirow{2}{*}{$\begin{array}{c}\text { Functional genes } \\
\text { (nrfA) } \\
\text { Dissimilarity } \\
\text { nitrate reducing } \\
\text { bacteria }\end{array}$} \\
\hline nrfA2R & 59.6 & $\begin{array}{l}\text { CCG GCA CTT TCG } \\
\text { AGC CC }\end{array}$ & & & \\
\hline F1norA & 58.7 & $\begin{array}{l}\text { CAG ACC GAC GTG } \\
\text { TGC GAA AG }\end{array}$ & & $\begin{array}{l}\text { Pre-heating at } 50{ }^{\circ} \mathrm{C} \text { for } 2 \mathrm{~min}, \\
\text { pre-denaturation at } 95^{\circ} \mathrm{C} \text { for }\end{array}$ & \multirow{2}{*}{$\begin{array}{c}\text { Functional genes } \\
\text { (nxrA) } \\
\text { Nitrite oxidizing } \\
\text { bacteria }\end{array}$} \\
\hline R1norA & 55.4 & $\begin{array}{l}\text { TCY ACA AGG AAC } \\
\text { GGA AGG TC }\end{array}$ & $322 \mathrm{bp}$ & $\begin{array}{l}10 \mathrm{~min} \text {, denaturation at } 95^{\circ} \mathrm{C} \text { for } \\
15 \mathrm{~s} \text {, annealing at } 57^{\circ} \mathrm{C} \text { for } 30 \mathrm{~s} \text {, and } \\
\text { extension at } 72^{\circ} \mathrm{C} \text { for } 30 \mathrm{~s}\end{array}$ & \\
\hline Uni-907R & 49.9 & $\begin{array}{l}\text { CCG TCA ATT CMT } \\
\text { TTG AGT TT }\end{array}$ & & $\begin{array}{l}\text { Pre-heating at } 50^{\circ} \mathrm{C} \text { for } 2 \mathrm{~min}, \\
\text { pre-denaturation at } 95^{\circ} \mathrm{C} \text { for }\end{array}$ & \multirow[b]{2}{*}{$\begin{array}{l}\text { FeRB (Albidiferax } \\
\text { ferrireducens) }\end{array}$} \\
\hline RdoR-RC & 54.3 & $\begin{array}{c}\text { GAC CTG CAT TTG TGA } \\
\text { CTG YA }\end{array}$ & $312 \mathrm{bp}$ & $\begin{array}{l}10 \mathrm{~min} \text {, denaturation at } 95^{\circ} \mathrm{C} \text { for } \\
15 \mathrm{~s} \text {, annealing at } 52^{\circ} \mathrm{C} \text { for } 45 \mathrm{~s} \text {, and } \\
\text { extension at } 72{ }^{\circ} \mathrm{C} \text { for } 45 \mathrm{~s}\end{array}$ & \\
\hline She 120F & 61.9 & $\begin{array}{l}\text { GCC TAG GGA TCT } \\
\text { GCC CAG TCG }\end{array}$ & & $\begin{array}{l}\text { Pre-heating at } 50^{\circ} \mathrm{C} \text { for } 2 \mathrm{~min} \text {, } \\
\text { pre-denaturation at } 95^{\circ} \mathrm{C} \text { for }\end{array}$ & \\
\hline She $220 \mathrm{R}$ & 53.2 & $\begin{array}{l}\text { CTA GGT TCA TCC } \\
\text { AAT CGC G }\end{array}$ & $100 \mathrm{bp}$ & $\begin{array}{c}10 \mathrm{~min} \text {, denaturation at } 95^{\circ} \mathrm{C} \text { for } \\
15 \mathrm{~s} \text {, annealing at } 60^{\circ} \mathrm{C} \text { for } 60 \mathrm{~s} \text {, and } \\
\text { extension at } 72{ }^{\circ} \mathrm{C} \text { for } 30 \mathrm{~s} \\
(40 \text { cycles })\end{array}$ & $\begin{array}{l}\text { FeRB (Shewanella } \\
\text { spp.) }\end{array}$ \\
\hline
\end{tabular}


Table A1. Cont.

\begin{tabular}{|c|c|c|c|c|c|}
\hline Primers & $\begin{array}{l}\mathrm{Tm} \\
\left({ }^{\circ} \mathrm{C}\right)\end{array}$ & Sequence & $\begin{array}{l}\text { Band } \\
\text { Lenght }\end{array}$ & PCR Cycles & Target \\
\hline Ferrovum $643 \mathrm{~F}$ & 55.7 & $\begin{array}{c}\text { ACA GAC TCT AGC } \\
\text { TTG CCA GT }\end{array}$ & \multirow[b]{2}{*}{$323 \mathrm{bp}$} & $\begin{array}{l}\text { Pre-heating at } 50^{\circ} \mathrm{C} \text { for } 2 \mathrm{~min}, \\
\text { pre-denaturation at } 95^{\circ} \mathrm{C} \text { for }\end{array}$ & \multirow[b]{2}{*}{$\begin{array}{l}\text { FeOB (Ferrovum } \\
\text { myxofaciens) }\end{array}$} \\
\hline Uni-338F-RC & 59.4 & $\begin{array}{l}\text { ACT CCT ACG GGA } \\
\text { GGC AGC }\end{array}$ & & $\begin{array}{l}10 \mathrm{~min} \text {, denaturation at } 95^{\circ} \mathrm{C} \text { for } \\
15 \mathrm{~s} \text {, annealing at } 57^{\circ} \mathrm{C} \text { for } 45 \mathrm{~s} \text {, and } \\
\text { extension at } 72^{\circ} \mathrm{C} \text { for } 45 \mathrm{~s}\end{array}$ & \\
\hline Uni-907R-RC & 49.9 & $\begin{array}{l}\text { AAA CTC AAA KGA } \\
\text { ATT GAC GG }\end{array}$ & \multirow[b]{2}{*}{110 bp } & $\begin{array}{l}\text { Pre-heating at } 50^{\circ} \mathrm{C} \text { for } 2 \mathrm{~min}, \\
\text { pre-denaturation at } 95^{\circ} \mathrm{C} \text { for }\end{array}$ & \multirow{2}{*}{$\begin{array}{c}\text { FeOB } \\
\text { (Acidimicrobium) }\end{array}$} \\
\hline Amf995 & 60.5 & $\begin{array}{l}\text { CTC TGC GGC TTT TCC } \\
\text { CTC CAT G }\end{array}$ & & $\begin{array}{l}10 \mathrm{~min} \text {, denaturation at } 95^{\circ} \mathrm{C} \text { for } \\
15 \mathrm{~s} \text {, annealing at } 52^{\circ} \mathrm{C} \text { for } 45 \mathrm{~s} \text {, and } \\
\text { extension at } 72{ }^{\circ} \mathrm{C} \text { for } 45 \mathrm{~s}\end{array}$ & \\
\hline
\end{tabular}

\section{References}

1. Mancinelli, R.L. 2-What good is nitrogen: An evolutionary perspective. In Evolution on Planet Earth; Rothschild, L.J., Lister, A.M., Eds.; Academic Press: London, UK, 2003; pp. 25-34, ISBN 978-0-12-598655-7.

2. Thamdrup, B. New Pathways and Processes in the Global Nitrogen Cycle. Annu. Rev. Ecol. Evol. Syst. 2012, 43, 407-428. [CrossRef]

3. Fiore, C.L.; Jarett, J.K.; Olson, N.D.; Lesser, M.P. Nitrogen fixation and nitrogen transformations in marine symbioses. Trends Microbiol. 2010, 18, 455-463. [CrossRef]

4. Barnard, R.; Leadley, P.W.; Hungate, B.A. Global change, nitrification, and denitrification: A review. Glob. Biogeochem. Cycles 2005, 19, 1-13. [CrossRef]

5. Thakur, I.S.; Medhi, K. Nitrification and denitrification processes for mitigation of nitrous oxide from waste water treatment plants for biovalorization: Challenges and opportunities. Bioresour. Technol. 2019, 282, 502-513. [CrossRef] [PubMed]

6. Huang, H.; Xiao, X.; Yan, B.; Yang, L. Ammonium removal from aqueous solutions by using natural Chinese (Chende) zeolite as adsorbent. J. Hazard. Mater. 2010, 175, 247-252. [CrossRef]

7. Li, M.; Zhu, X.; Zhu, F.; Ren, G.; Cao, G.; Song, L. Application of modified zeolite for ammonium removal from drinking water. Desalination 2011, 271, 295-300. [CrossRef]

8. Kim, T.; Gorski, C.A.; Logan, B.E. Ammonium Removal from Domestic Wastewater Using Selective Battery Electrodes. Environ. Sci. Technol. Lett. 2018, 5, 578-583. [CrossRef]

9. McCarty, P.L. What is the Best Biological Process for Nitrogen Removal: When and Why? Environ. Sci. Technol. 2018, 52, 3835-3841. [CrossRef] [PubMed]

10. Zhu, G.; Peng, Y.; Li, B.; Guo, J.; Yang, Q.; Wang, S. Biological Removal of Nitrogen from Wastewater. Rev. Environ. Contam. Toxicol. 2008, 192, 159-195.

11. Le, C.P.; Nguyen, H.T.; Nguyen, T.D.; Nguyen, Q.H.M.; Pham, H.T.; Dinh, H.T. Ammonium and organic carbon co-removal under feammox-coupled-with-heterotrophy condition as an efficient approach for nitrogen treatment. Sci. Rep. 2021, 11, 784. [CrossRef]

12. Cao, S.; Zhou, Y. New direction in biological nitrogen removal from industrial nitrate wastewater via anammox. Appl. Microbiol. Biotechnol. 2019, 103, 7459-7466. [CrossRef]

13. Koren, D.W.; Gould, W.D.; Bédard, P. Biological removal of ammonia and nitrate from simulated mine and mill effluents. Hydrometallurgy 2000, 56, 127-144. [CrossRef]

14. Han, B.; Butterly, C.; Zhang, W.; He, J.Z.; Chen, D. Adsorbent materials for ammonium and ammonia removal: A review. J. Clean. Prod. 2021, 283, 124611. [CrossRef]

15. Clément, J.-C.; Shrestha, J.; Ehrenfeld, J.G.; Jaffé, P.R. Ammonium oxidation coupled to dissimilatory reduction of iron under anaerobic conditions in wetland soils. Soil. Biol. Biochem. 2005, 37, 2323-2328. [CrossRef]

16. Zhu, T.T.; Zhang, Y.B.; Liu, Y.W.; Zhao, Z. sheng Electrostimulation enhanced ammonium removal during Fe(III) reduction coupled with anaerobic ammonium oxidation (Feammox) process. Sci. Total Environ. 2021, 751, 141703. [CrossRef] [PubMed]

17. Zhu, J.; Li, T.; Liao, C.; Li, N.; Wang, X. A promising destiny for Feammox: From biogeochemical ammonium oxidation to wastewater treatment. Sci. Total Environ. 2021, 790, 148038. [CrossRef] [PubMed]

18. Tan, X.; Xie, G.-J.; Nie, W.-B.; Xing, D.-F.; Liu, B.-F.; Ding, J.; Ren, N.-Q. Fe (III)-mediated anaerobic ammonium oxidation: A novel microbial nitrogen cycle pathway and potential applications. Crit. Rev. Environ. Sci. Technol. 2021, 1-33. [CrossRef]

19. Sawayama, S. Possibility of anoxic ferric ammonium oxidation. J. Biosci. Bioeng. 2006, 101, 70-72. [CrossRef]

20. Zhu, T.T.; Lai, W.X.; Zhang, Y.B.; Liu, Y.W. Feammox process driven anaerobic ammonium removal of wastewater treatment under supplementing Fe(III) compounds. Sci. Total Environ. 2022, 804, 149965. [CrossRef] [PubMed]

21. Huang, S.; Jaffé, P.R. Isolation and characterization of an ammonium-oxidizing iron reducer: Acidimicrobiaceae sp. A6. PLoS ONE 2018, 13, e0194007. [CrossRef]

22. Yang, W.H.; Weber, K.A.; Silver, W.L. Nitrogen loss from soil through anaerobic ammonium oxidation coupled to iron reduction. Nat. Geosci. 2012, 5, 538-541. [CrossRef] 
23. Huang, S.; Chen, C.; Peng, X.; Jaffé, P.R. Environmental factors affecting the presence of Acidimicrobiaceae and ammonium removal under iron-reducing conditions in soil environments. Soil. Biol. Biochem. 2016, 98, 148-158. [CrossRef]

24. Zhu, J.; Yan, X.; Zhou, L.; Li, N.; Liao, C.; Wang, X. Insight of bacteria and archaea in Feammox community enriched from different soils. Environ. Res. 2022, 203, 111802. [CrossRef]

25. Franson, M.A.H.; Eaton, A.D.; Greenberg, A.E.; Clesceri, L.S. Standard Methods for the Examination of Water and Wastewater; American Public Health Association (APHA): Washington, DC, USA, 1995.

26. Shu, D.; He, Y.; Yue, H.; Yang, S. Effects of Fe (II) on microbial communities, nitrogen transformation pathways and iron cycling in the anammox process: Kinetics, quantitative molecular mechanism and metagenomic analysis. RSC Adv. 2016, 6, 68005-68016. [CrossRef]

27. Li, X.; Hou, L.; Liu, M.; Zheng, Y.; Yin, G.; Lin, X.; Cheng, L.; Li, Y.; Hu, X. Evidence of Nitrogen Loss from Anaerobic Ammonium Oxidation Coupled with Ferric Iron Reduction in an Intertidal Wetland. Environ. Sci. Technol. 2015, 49, 11560-11568. [CrossRef]

28. Shuai, W.; Jaffé, P.R. Anaerobic ammonium oxidation coupled to iron reduction in constructed wetland mesocosms. Sci. Total Environ. 2019, 648, 984-992. [CrossRef] [PubMed]

29. Cornell, R.M.; Schwertmann, U. The Iron Oxides: Structure, Properties, Reactions, Occurrences and Uses; John Wiley \& Sons: Hoboken, NJ, USA, 2003; ISBN 3527302743.

30. Chen, K.; Lei, H.; Li, Y.; Li, H.; Zhang, X.; Yao, C. Physical and chemical characteristics of waste activated sludge treated with electric field. Process Saf. Environ. Prot. 2011, 89, 327-333. [CrossRef]

31. Al-Dawery, S.K. Conditioning process and characterization of fresh activated sludge. Int. J. Eng. Sci. Technol. $2015,10,692-711$.

32. Lavergne, C.; Bovio-Winkler, P.; Etchebehere, C.; García-Gen, S. Towards centralized biogas plants: Co-digestion of sewage sludge and pig manure maintains process performance and active microbiome diversity. Bioresour. Technol. 2020, 297, 122442. [CrossRef]

33. Wright, C.L.; Schatteman, A.; Crombie, A.T.; Murrell, J.C.; Lehtovirta-Morley, L.E. Inhibition of Ammonia Monooxygenase from Ammonia-Oxidizing Archaea by Linear and Aromatic Alkynes. Appl. Environ. Microbiol. 2020, 86, e02388-19. [CrossRef]

34. Lehtovirta-Morley, L.E. Ammonia oxidation: Ecology, physiology, biochemistry and why they must all come together. FEMS Microbiol. Lett. 2018, 365, fny058. [CrossRef] [PubMed]

35. Francis, C.A.; Roberts, K.J.; Beman, J.M.; Santoro, A.E.; Oakley, B.B. Ubiquity and diversity of ammonia-oxidizing archaea in water columns and sediments of the ocean. Proc. Natl. Acad. Sci. USA 2005, 102, 14683-14688. [CrossRef]

36. Fredrickson, J.K.; Gorby, Y.A. Environmental processes mediated by iron-reducing bacteria. Curr. Opin. Biotechnol. 1996, 7, 287-294. [CrossRef]

37. Esther, J.; Sukla, L.B.; Pradhan, N.; Panda, S. Fe (III) reduction strategies of dissimilatory iron reducing bacteria. Korean J. Chem. Eng. 2014, 32, 1-14. [CrossRef]

38. Lu, S.; Chourey, K.; Reiche, M.; Nietzsche, S.; Shah, M.B.; Neu, T.R.; Hettich, R.L.; Kï $i \frac{1}{2}$ sel, K. Insights into the Structure and Metabolic Function of Microbes That Shape Pelagic Iron-Rich Aggregates ("Iron Snow"). Appl. Environ. Microbiol. 2013, 79, 4272-4281. [CrossRef]

39. Jin, C.Z.; Zhuo, Y.; Wu, X.; Ko, S.R.; Li, T.; Jin, F.J.; Ahn, C.Y.; Oh, H.M.; Lee, H.G.; Jin, L. Genomic and Metabolic Insights into Denitrification, Sulfur Oxidation, and Multidrug Efflux Pump Mechanisms in the Bacterium Rhodoferax sediminis sp. nov. Microorganisms 2020, 8, 262. [CrossRef]

40. Finneran, K.T.; Johnsen, C.V.; Lovley, D.R. Rhodoferax ferrireducens sp. nov., a psychrotolerant, facultatively anaerobic bacterium that oxidizes acetate with the reduction of Fe (III). Int. J. Syst. Evol. Microbiol. 2003, 53, 669-673. [CrossRef]

41. Johnson, D.B.; Hallberg, K.B.; Hedrich, S. Uncovering a Microbial Enigma: Isolation and Characterization of the StreamerGenerating, Iron-Oxidizing, Acidophilic Bacterium 'Ferrovum myxofaciens'. Appl. Environ. Microbiol. 2014, 80, 672-680. [CrossRef]

42. Kuenen, J.G. Anammox bacteria: From discovery to application. Nat. Rev. Microbiol. 2008, 6, 320-326. [CrossRef]

43. Kuypers, M.M.M.; Sliekers, A.O.; Lavik, G.; Schmid, M.; Jørgensen, B.B.; Kuenen, J.G.; Sinninghe Damsté, J.S.; Strous, M.; Jetten, M.S.M. Anaerobic ammonium oxidation by anammox bacteria in the Black Sea. Nature 2003, 422, 608-611. [CrossRef]

44. Li, X.; Yuan, Y.; Huang, Y.; Liu, H.W.; Bi, Z.; Yuan, Y.; Yang, P.B. A novel method of simultaneous $\mathrm{NH}_{4}{ }^{+}$and $\mathrm{NO}_{3}{ }^{-}$removal using Fe cycling as a catalyst: Feammox coupled with NAFO. Sci. Total Environ. 2018, 631, 153-157.

45. Zhou, G.-W.; Yang, X.-R.; Li, H.; Marshall, C.W.; Zheng, B.-X.; Yan, Y.; Su, J.-Q.; Zhu, Y.-G. Electron Shuttles Enhance Anaerobic Ammonium Oxidation Coupled to Iron (III) Reduction. Environ. Sci. Technol. 2016, 50, 9298-9307. [CrossRef] [PubMed]

46. Huang, S.; Jaffé, P.R. Characterization of incubation experiments and development of an enrichment culture capable of ammonium oxidation under iron-reducing conditions. Biogeosciences 2015, 12, 769-779. [CrossRef]

47. Kappler, A.; Wuestner, M.L.; Ruecker, A.; Harter, J.; Halama, M.; Behrens, S. Biochar as an Electron Shuttle between Bacteria and Fe (III) Minerals. Environ. Sci. Technol. Lett. 2014, 1, 339-344. [CrossRef]

48. Feng, L.; Li, J.; Ma, H.; Chen, G. Effect of Fe (II) on simultaneous marine anammox and Feammox treating nitrogen-laden saline wastewater under low temperature: Enhanced performance and kinetics. Desalination 2020, 478, 114287. [CrossRef] 